\title{
Akademik Yolculukta Mentorün Rolü
}

\section{Role of the Mentor in Academic Journey}

\section{Demet Soylu*}

$\ddot{\boldsymbol{O}} z$

Bu çalışma, bir araştırma görevlisinin akademik hayatında mentorün rolünü ortaya koymayı amaçlamaktadır.

Anahtar Sözcükler: Mentor; mentorlük; akademik yolculuk.

\begin{abstract}
This study aims to put forward the role of a mentor in the academic life of a research assistant.
\end{abstract}

Keywords: Mentor; mentorship; academic journey.

Akademik Yolculuğumu Farklılaştıran Değerli Mentorüm Doçent. Dr. Gülten Alır Derbent'e ithafen;

Oxford İngilizce Sözlük’e (2021) göre mentor diğer kişilere destek ve rehberlik sunan kişidir. Mentor, danışanına belirli konularda tavsiyelerde bulunmaktadır, onları yönlendirmektedir ve kişisel gelişimlerine katkıda bulunmaktadır. Mentorlük, bir kavram, süreç, gelişimsel deneyim ve bir dizi etkinlik (Crisp ve Cruz, 2009) olarak tanımlanmaktadır. Mentorlügün ilk aşamasında iki kişi karşılıklı bir ilişki sürecine başlamaktadır. Danışan ve mentor arasındaki eşleşme süreci sosyal veya akademik çevredeki etkileşimler sonucunda gerçekleşmektedir. İki taraf da ortak ilgi alanları, eğilimler, tercihler, çalışma konuları, araştırma alanları ekseninde buluşmaktadır. Potansiyel danışanlar takdir ettikleri, deneyimlerinden öğrenmek istedikleri bilgi ve becerilerinden etkilendikleri bir mentor aramaktadır. Mentorler de tecrübelerini danışanlarına aktarmak istemekte ve bu süreçte danışanıyla birlikte çalışarak gerçekleştirdikleri eylemleri verimli bir bilgi paylaşım ve değişim sürecine dönüştürmektedir. Mentorler, geniş bir yelpazede danışanlarına destek olurlar, danışmanlık ve rehberlik sunarlar (American Psychological Association, 2016).

- Mesleki yaşamında genel ve özel konularda danışmanlık

- Belirli soru ve konular ekseninde danışmanlık

\footnotetext{
*Ankara Yıldırım Beyazıt Üniversitesi, Bilgi ve Belge Yönetimi Bölümü, Ankara, Türkiye. E-posta: bunchnoble@gmail.com

Ankara Yildırım Beyazıt University, Department of Information Management, Ankara, Turkey. Email:bunchnoble@gmail.com
}

Geliş Tarihi-Received: 01.09.2021

Kabul Tarihi - Accepted: 03.09.2021

Yayımlanma Tarihi - Published: 30.09.2021 
- Etik açıdan rehberlik

- Erken kariyer evresi

- Etik konular açısından rehberlik

- Mesleki çevre ve kurumlar açısından danışmanlık

- Mesleki kimlik gelişimi

İş yaşamında ve okul yaşamında bir mentor eşliğinde çalışmak, bireyin çalışma performansını ve motivasyonunu olumlu yönde etkilemektedir. Birey, mentorü sayesinde daha emin adımlarla yürüyebilmektedir. Bu durum da hedef belirleme ve hedeflere ulaşılma sürecinin de verimli hale gelmesini sağlamaktadır. Akademik çalışma hayatında da mentorlüğün rolü büyüktür. Bir araştırma görevlisinin akademik yaşamında mentor önemli bir yere sahiptir. Akademik yolculuğa eşlik eden bir mentor, kendi deneyimlerini, bilgi ve becerisini paylaşarak araştırma görevlisinin nasıl ilerlemesi, nasıl kendini geliştirmesi gerektiği ve karşılaşılan zorlukları nasıl çözümleyeceği konusunda onu yönlendirmektedir. Araştırma görevlisine rehberlik eden ve onu akademik konularda yönlendiren mentorlerin varlığı araştırma görevlilerinin akademik becerilerinin gelişmesine katkıda bulunmaktadır.

İyi mentorler mesafe ve zaman farkı tanımaksızın kişinin yanında olmaktadır. Nerede olursa olsunlar desteklerini her daim hissetmek mümkündür. Bu okuyucu mektubunu yazma konusundaki motivasyon ve ilhamım kendi özel deneyimime dayanmaktadır. Araştırma görevliliği sürecime ve akademik yaşamıma eşlik eden, değerli fikirleri ve görüşleriyle akademik yaşamımı farklı kılan, tavsiyeleri ile süreci iyileştiren, sonsuz destekleri ile beni her zaman motive eden ve başarabileceğime inandıran, varlığını her daim tüm yüreğimle hissettiğim değerli mentorüm Doç. Dr. Gülten Alır Derbent ile olan etkileşimimiz hayatımda iz bırakan önemli bir mentorlük örneğidir. İçinden geçmekte olduğum akademik yolculuğumda değerli mentorüm akademik yaşamıma yön vermeye çalışmış, kendimi geliştirebileceğim ortamlar konusunda bilgi ve tecrübelerini benimle paylaşmış, yeni bilgi ve beceriler kazanacağım firsatlar sunmuştur. Bu yolculuktaki gelişim sürecimle ilgili geri bildirimlerini paylaşarak eksik olduğum noktalarda bilgi ve becerilerimi iyileştirmeme yardımcı olmuştur. İlerleyen mevcut durumda da desteklerini esirgemeyerek akademik yaşamıma dokunmaya ve yoluma 1şık tutmaya devam etmektedir. Yolumu aydınlattığı ve bu süreçte yanımda olmaya devam ettiği için değerli mentorüme teşekkürlerimi sunmak isterim. Varlığı ve bana sunduğu mentorlük desteği, öğretici ve yararlı olmakla birlikte bu yolculukta eşsiz bir deneyimdir.

Araştırma görevliliği sürecinde mentorlük ilişkisi akademik gelişim açısından çok önemlidir. Bireyin birlikte çalışabilirlik açısından uyum yakaladığı ve dengeyi bulabildiği bir mentorden destek alması ufuk açıcı bir deneyime dönüşecektir.

\section{Kaynakça}

American Psychological Association. (2016). Introduction to mentoring: A guide for mentors and mentees. https://www.apa.org/education-career/grad/intro-mentoring.pdf.

Crisp, G. ve Irene, C. (2009). Mentoring college students: A critical review of the literature between 1990 and 2007. Research in Higher Education, 50(6), 525-545.

Mentor. (2021). Oxford English Dictionary. https://www.oed.com/ 